\title{
POLITICIANS AS CULTURAL SELECTORS: FAVOURING OR DISCOURAGING YOUTH PARTICIPATION
}

\author{
MARCO BOFFI
}

\begin{abstract}
An evolutionary perspective can be applied to the analysis of cultural phenomena to describe how inheritance mechanisms can account for the development of cultural traits in a given environment. This paper aims to describe the psychosocial functioning of the political system from this perspective, focusing on the role of politicians as cultural selectors. As they are in charge of legislation, politicians have a key role in steering the evolution of cultural norms. In particular they play a leading part in determining access to traditional forms of participation, such as parties. We interviewed a panel of political experts to explore the selective mechanisms shaping the Italian political system. The results show that co-option is the main method of selecting new members for parties, with the aim of keeping power within well-established structures. The specific features of the Italian political environment explain its decreasing ability to attract young activists.

Key words: cultural selection; political participation; civic participation; professional politics; activism; goodwork
\end{abstract}

\section{Introduction}

\section{Professional politicians: an elusive definition}

An eighteen-year-old girl, who suddenly became famous because of her friendship with the then Italian Prime Minister, Silvio Berlusconi, declared she wanted to be "a showgirl. [...] I'm also interested in politics [...] I want to run for parliament. 'Papi' Silvio will arrange it" (Agrippa 2009). This is one of many episodes that have characterized Italian politics in

\footnotetext{
${ }^{1}$ The distinction made by Weber (1919) between people living "for" politics and people living "off" politics became a milestone. It distinguished the former, those who are keenly involved in political activities, from the latter, who also make a career for themselves in this area. Although scholars have outlined the dangers of the phenomenon of the professionalization of politics producing a constant increase in the second group (Petracca 1991), the dividing line in present society is blurred. The notion of "profession" itself has been shown to be inadequate at the very least in helping us better define the borders of professional politics. As there is general agreement about the need to develop a comparative approach, across different professions and nations (Abbott 1988; Evetts 1999; 2003; Orzack 1998), the subject itself remains loosely defined. Establishing a precise definition of the notion of profession became of little interest to sociologists: "most scholars have moved in a different direction to study the work and non-work activities of professional groups and how they and allied parties use the discourse of professionalism to realize their goals" (Bourgeault, Benoit, Hirschkorn 2009, 475).
} 
recent years, that is, people of dubious competence at the very least having access to electoral competition. The continued perception that the political system lacks effective selective mechanisms has exacerbated the weight of such phenomena. Our study will highlight the functioning of such mechanisms in a cultural evolutionary perspective.

The debate on which skills should be promoted in politics often includes the question of whether or not politicians were-or else should be-a professional class. We are not interested in establishing whether this classification applies or not ${ }^{1}$, but for the purpose of this paper, we must note that: "Professionalism requires professionals to be worthy of that trust $[\ldots]$ and not use their knowledge for fraudulent purposes. In return for professionalism in client relations, some professionals are rewarded with authority, privileged rewards and high status" (Evetts 2006, 134). This statement pinpoints two important aspects in relation to our study. The first focuses on the subject of trust, entailing the notion of responsibility; the second expands the investigation to include the relations professional spheres have with society at large. Starting from these two points, the aim of the present study is to apply a psychosocial model that allows us to place politicians at the centre of the selective process into the world of politics.

\section{Politics: from profession to professional realm}

As far as responsibility is concerned, we refer to the concept developed by Gardner on morality and ethics $(2006 ; 2010)$. He described neighbourly morality as the judgment that guides the individual's behaviour when interacting with people met on a daily basis or with whom there is a reciprocal relationship. Gardner focused on the ethics of roles that direct the individual's actions in modern interactions characterized by occasional exchange, a possible lack of personal contact and the importance of the formal role. According to Gardner, the former is an attribute we were prepared for by genetic evolution over the course of time, while the latter is a characteristic that has mainly been created by culture and that has become fundamental to the ability to act adequately in modern complex societies. In the evolutionary perspective both aspects pass through a process of selection that enables the environmentally fittest to survive, as is the case with genetic and extra-genetic traits (Jablonka, Lamb 2005). According to Gardner, the ethics of roles is fundamental in shaping the public aspect of individuals, affecting their qualities as workers and as citizens in general. Therefore, a member of the collectivity who complies with these ethics will avoid compromised (Gardner 2005) or irresponsible work (Gardner 2007) and operate responsibly in her various roles in the society (Horn, Gardner 2007).

This idea of responsibility was fruitfully integrated in a wider perspective in the GoodWork Project (GoodWork Project Team 2008), aimed at describing the characteristics that work must have in order for it to become a point of reference for the individual and society. The authors of the project have wisely avoided using the term profession, developing their own original terminology instead in order to portray the elements of their conceptual model. We propose to use this psychosocial perspective (Gardner, Csikszentmihalyi, Damon 2001) to describe politics, as it offers rich insights for our purpose. The researchers coined the term "professional realm" to describe professions in general: this expression includes four other elements that we will briefly explore in relation to politics. 
- Individual practitioners. They represent people who decide to gain knowledge in politics by following appropriate training. In this category we shall therefore include both politicians and activists that undergo similar conventional political preparation albeit to different degrees — as included, for example, among the gladiator activities described by Milbrath (1965). Similarly, we also want to consider people involved in unconventional action-e.g. boycotting, occupying (Barnes, Kaase 1979; Dalton 1988; Dalton 2007).

- Domain. This consists of the set of knowledge and skills that belongs to the symbolic system recognized by practitioners. From this perspective culture is the result of numerous domains competing against each other, and they can be divided into more specific sub-domains. Hence we can consider executive and legislative power to be the domain pertaining to politics. Moreover, a domain can be divided up according to two main components. Ideas, which represents the actual competences and procedures to be transmitted to new practitioners-e.g. for politics the information contained in constitutions and codes. An ethical dimension, that is the rules, written or unwritten, that reassure the collectivity that political experts will not use their knowledge only for their own interest. Nowadays this is a crucial issue for politics, especially in Italy.

- Field. This represents the roles held by individual practitioners when putting their knowledge into practice. Depending on the stage of the career, three main roles can be described. Gatekeepers, who "influence the standards of the domain by determining what kind of work and which workers are considered to be acceptable or innovative" (Gardner, Gregory, Csikszentmihalyi, Damon, Michaelson 2001, 31), as national politicians do. Expert practitioners, the great majority of a field, and active at the local level. Apprentices, who have little power at the present moment but will guarantee the survival of the professional realm. In politics it is hard to attract apprentices, and researchers have recorded decreasing levels of participation in conventional activities (Blais, Gidengil, Nevitte, Nadeau 2004; Lyons, Alexander 2000; Miller, Shanks 1996) but also a general disaffection with politics (Buzzi, Cavalli, de Lillo 2007).

- Stakeholders. The fourth element refers to the social actors affected by the actions of practitioners. They can be divided into two groups. Shareholders are "the people who in effect own a company [...] and have expectations for its performance" (Gardner, Csikszentmihalyi, Damon 2001, 26); politically speaking this definition is applied to the electoral base of a given party, which is interested in electoral success and the ability to carry out its manifesto in practice. The second group is the general public, that is, the rest of society, which is influenced by the decisions made in the professional realm but has no direct and specific relation to it. In this model the citizens find themselves in this position, being affected by politicians' choices even if they have not voted for them. We are referring to a party-related situation, but we can observe that the relationship that a civic association has with its own supporters and the general public is similar.

Society contains several professional realms (e.g. medicine, economics, politics) competing in a Darwinian way to survive and transmit their symbols. The state of health of a realm, such as politics, is measured by the alignment occurring between several factors. The values conveyed within the domain (i.e. in this case laws and legal codes) must be aligned with the cultural environment. This means that other realms, like medicine or economics, must accept the area of expertise defined by politics: hence they will recognize that the laws 
provided are good. Moreover, the expectations of the field (i.e. in this case politicians) must be aligned with those of the stakeholders (i.e. electors and other citizens). Finally, the domain and field must match: there must be a genuine connection between the declared principles and the actual conduct. As all the elements involved in this alignment process are constantly changing, it is a dynamic model describing how realms move between positions of alignment and misalignment.

\section{Research hypotheses}

Viewing the course of Italian politics through this lens we can recognize different phases. From the end of WWII until the 1970s, the political realm had an important role as it was able to engage the masses thanks to its aligned position in society. At the end of the 1970s and the beginning of the 1980s it faced a process of misalignment, characterized by the citizens rejecting people and institutions linked to politics. At the time the ideologies associated with political knowledge lost their interpretative power (Craveri 1996; Crainz 2009; Galli della Loggia 1980). The shift away from public issues to individual interests intensified at the beginning of the 1990s, when the corruption in the political system became blatant during the numerous trials known as Mani Pulite (Clean Hands). On the basis of these factors, our hypothesis is that by investigating the present political system as a political realm we may pinpoint important selective mechanisms. In our view these may account for young people withdrawing from conventional forms of political participation. Moreover, this perspective may emphasize the role of individual politicians in this phenomenon.

\section{Method}

\section{Participants and procedure}

In accordance with the method developed for the GoodWork Project (Gardner, Gregory, Csikszentmihalyi, Damon, Michaelson 2001), we identified thirteen trustees who are considered to be experts in Italian politics. The ages of the participants ranged from between 57 to 90 years of age $(\mathrm{M}=67.1, \mathrm{SD}=11.48)$. They came from the northern (8), central (3) and southern (2) regions and three of them were women. We selected a panel of national and international high level observers of national politics, belonging to three different fields: four historians and four political scientists-holding key positions in institutions devoted to the study of this issue-, five journalists with central roles in the main national newspapers. The research was conducted between December 2009 and June 2010. Interviews were audio recorded in Italian with the participants' permission, under guarantees of anonymity, and lasted up to two hours.

\section{Interview grid and analysis}

The grid for the semi-structured interview was realized on the basis of the original GoodWork protocols (Gardner, Gregory, Csikszentmihalyi, Damon, Michaelson 2001), adapted for the Italian context and the political issue. It was divided into three main sections. The first was devoted to exploring the present political system. It comprised four questions 
about the main goals to be pursued in the public interest, the main rewarded/discouraged behaviours, strong and weak points of current political action, and training for the younger generations. The second part focused on the names of Italian politicians enacting good forms of politics and giving concrete examples of the principles previously stated. The last section focused on the hypothetic actions of a good politician-having the positive characteristics of those mentioned in the second part—and through eleven questions investigated the obstacles she would face in the contemporary political environment.

The data recorded, alongside the notes taken at the end of each interview, were subsequently analyzed using ATLAS.ti 5.5 software. This enabled us to develop a qualitative analysis supported by ease of systematization. As no research had previously applied these hypotheses to politics, we had no specific expectations nor did we have a fixed grid for our analysis. Hence we developed an interpretative investigation, assigning a text-grounded code to each extract from the interviews. This allowed us to identify the nodes of the discussion, useful in creating a conceptual map. In order to preserve the anonymity of the participants, the content of the interviews will be presented in code form only, followed by gender $(\mathrm{M} / \mathrm{F})$ and the field in which the interviewee is engaged (hist., pol., jour.).

\section{Results and discussion}

The global analysis produced eight main aspects that indicate the mechanisms of the political realm useful in appraisal its functioning: effectiveness, additive mediation, dialogic leadership, long term vision, progressive competences, removal of corruption, instrumental power, horizontal communication. For the purposes of this article we will focus on instrumental power.

\section{Handling power}

The issue of power was cited frequently as the central interpretative key for the political realm. The manner in which it is handled enables us to discern positive and negative forms of political action, in particular when they directly affect selective mechanisms. According to participant B4 power was the unit of measure par excellence chosen by a politician to appraise her own actions, and this criterion was preferred over common well-being. "A politician when choosing between a good deed without outputs in terms of power and a bad action bringing results [...] will always choose the second" (B4, M, hist.). Hence power played a key role, but it need not simply be conceived in negative terms since "power means also the power to do, then it is very satisfying, it's a good thing" (B4, M, hist.).

Therefore, in general terms, power must not be understood as a goal in itself, which would mean using it in a bad way, but as a way of completing the projects that the electorate has chosen, thus determining the electoral results. A successful way of managing power in politics lies in the ability to deal with the critical transition from political will to its implementation. This represented the dividing line between good and bad politics, affecting collective interests.

Hence in our analysis most of the statements coded as "power" were negatively framed not because of its intrinsic characteristics, as was the case with corruption, which is a threat 
to common goods per se, but because of the specific features assumed in the Italian political realm. In fact power was considered a positive tool for implementing abstract principles if managed efficiently and used in moderation:

the ideal politician should not impinge on sectors of society [...], should have a sense of the limits of politics, of the ability to exert influence on society without occupying it. [...] There are areas where a politician should agree not to enter, not in the sense of not taking care of it (B3, M, hist.).

The failure of the Italian political system lay in this inability: it was depicted as being very effective in obtaining power but not in using it for the public wellbeing.

\section{The need for conformism produces co-option}

This idea of power in Italian politics, and the way it was then used had a great impact on the principles behind the selection of new members of the political field. Since obtaining and maintaining power seemed to be the main objectives, the characteristics rewarded in those who engage in a political career were consistent with this need. Hence the first and most awarded trait was obedience, which "in politics [...], where power is the backbone, [...] is stronger than" in other realms (B4, M, hist.). A domain focused mainly on maintaining power will use co-option to identify and promote new members to the field. Principles such as the common good, although formally recognized as important, were sidelined because of the necessity to promote conformism, which meant that the pressing needs of parties could be defended - and by means of a specific tool: the present electoral law written by ex-minister Calderoli. In general, the functioning of the political system can be summarized in the words of one of the participants:

I am afraid that $[\ldots]$ there is a wide gap between what should be [...] the basic goals of a politician and the system of rewards and punishments, incentives and sanctions that the political system, as it exists in practice today, operates [...]. I don't think you can say that politicians who seem to pay more attention to the public interest, the common interest, who are more respectful of democratic norms, are particularly rewarded (C2, M, pol.).

\section{Unattractive to youth: ignoring competences}

Explicit comments were made about specific parties, in particular the two main parties present in Italy today, that is, the PD (the Democratic Party) and PDL (People of Freedom). Although emphasizing different aspects, most parties

in the selection of their representatives adopt quite unusual criteria. It is probably difficult to find $[. .$.$] an unambiguous criterion. [...] Certainly there are those who are skilled and prepared,$ together with others $[\ldots]$ who are in parliament because of criteria [...] rewarding aesthetic features, subjection (C4, F, pol.).

The use of shallow selective criteria based solely on media requirements was found in all the political parties across the board, with a damaging effect on the characteristics of individuals entering the political field at any level: "what I dislike is the selection of the 
leaders of society. I believe that co-option, regarding not only the centre-right but also the centre-left, has lowered the level of the political class and decreased the rate of renewal" (A4, M, jour.). This situation was undoubtedly favoured by the electoral law currently in force, endorsed by the majority of present parties. Therefore the parties survived as bodies determining the rules of the domain, but were not able to develop the ethical dimension. Moreover, the ideas they continued to transmit were entirely devoted to defending their own existence; over the years they lost the ability to provide political apprenticeships, needed to nurture professional competences in any given area. Operating on the basis of co-option, the parties only succeeded in enabling young people to engage in self-referential political activities, including strengthening personal networks. Due to "the absence of specific tasks relating to competition" (B3, M, hist.), apprentices did not have the opportunity to demonstrate and improve their competences. Being skilled in non-self-referential activities became unnecessary.

This mechanism thus awarded traits of conformism rather than creativity: "I think that it is more important [...] devotion than novelty [...], accepting a norm, a style, a way of speaking and especially a leadership is much more important" (A5, M, jour). Indeed, if creativity was compatible with the idea of loyalty to principles, it was not a characteristic of people who passively adapted to what was required because they were a member of the party.

I think that the important virtues include loyalty, not devotion: canine devotion to a leader can help to advance one's career but it is not desirable, loyalty is desirable, that is being honest and transparent, direct [...], without plotting and scheming in politics (C2, M, hist.).

Being autonomous and independent, not in the sense of anarchic behaviour, but as in having the ability to critically evaluate one's position in the party, were characteristics that were ignored if not rejected. This apparently paradoxical mechanism of selection was lucidly described by one of the historians who was interviewed:

Whoever wants to be a deputy must please the leader. You can please the leader only if you are obedient and devoted, not if you are skilled, this is politics. An average politician [...] in most cases chooses devotion rather than qualitative excellence. Because devotion is reassuring, whereas excellent quality is disturbing, because by having it you might somehow become a competitor, overshadowing him (B4, M, hist.).

Ultimately, this was one of the most influential characteristics of the political realm that contributed to young people turning away from politics, since "conformism doesn't spring from young people, conformism springs from adults" (A4, M, jour.). It is worth noting that most interviewees strongly associated this model with a higher levels of politics-for example they explicitly cited the parliament as being associated with flawed selection processes - and considered the roots to be the healthiest part of the whole system instead.

\section{Final comments}

Some remarks about the limitations of the study are necessary. The sample we selected for interview was obviously not representative; moreover it was unbalanced in terms of gender and territorial distribution. This notwithstanding, we were mainly focused on the 
high-level expertise of the interviewees. The results obtained were not universally valid. We took an emic perspective and considered our data strictly in relation to the context in which they were gathered. Hence the relations characterizing the components of our analysis referred to the present Italian political environment, and cannot be automatically transferred to a different context. Despite these limitations, this case study provides some interesting ideas about the potential for developing an investigation into political systems that goes beyond traditional politological and sociological issues, fruitfully integrating psychosocial elements.

\section{Conclusion}

According to the theoretical perspective chosen for our study, it is possible to investigate the changes in the political realm in terms of cultural selection, that is, the process that produces modifications in cultural traits favouring the survival of the fittest in a given environment (Cavalli-Sforza, Feldman 1981; Dawkins 1976/2006; Jablonka, Lamb 2005). As noted by Shennan:

Biological evolution is characterized by changing frequencies of genes in populations through time as a result of such processes as natural selection; likewise, cultural evolution refers to the changing distributions of cultural attributes in populations, which are affected by processes such as natural selection but also by others that have no analogue in genetic evolution (2008, 3175).

We claim that politicians represent one of those purely cultural processes, acting as cultural selectors. This unique role in the selective mechanism is due to the fact that they can directly influence the constitutions and laws that are considered a written depositary of the cultural evolution of a given society (Calegari, Massimini 1978; Massimini, Calegari 1979). They are therefore able to act as selectors at two levels. On the one hand they undertake "ordinary" selections like any individual does through daily behaviour: by choosing certain practices or using specific objects, we all select artefacts to be culturally transmitted (Inghilleri 1999). On the other hand politicians are responsible for a kind of meta-selection, or "direct" selection, operating overtly on legal codes. Like geneticists handling DNA, politicians can have a direct impact on the cultural code influencing the actions of the rest of the community through the exercise of legislative and executive power. Of course they must behave in accord with the citizens' will, but they hold a privileged position in managing such selection processes. This is the reason why we stress the role politicians have in determining the alignment-misalignment processes of the political realm. If Gardner et al. (2001) have already emphasized the importance of creators and leaders in changing realms, our data illustrate the impact of individual practitioners in general by showing how substantial and repeated misuse of power affects the functioning of the political realm. Although our analysis focuses mainly on politicians with representative roles in institutions, we argue that similar mechanisms apply also to political activists, who act as opinion leaders in their own networks (Vergani 2011).

The current Italian political system is mainly engaged in a struggle to maintain power. It interferes in other specific domains, such as economics, education or health; instead of 
securing the public interest, it does so to create a defensive network against the possible loss of its own power. The selective mechanisms enacted for such a purpose discourage conventional political engagement, pushing young generations towards other forms of civic participation. We claim that such strong misalignment with society is mainly due to politicians, who are in charge of the selection processes. In fact, there are two sources of disaffection with politics: 1) norms determining the functioning of politics, which offer too many privileges to politicians, and 2) the actual behaviour of politicians, which conflicts with declared principles and citizens' expectations. Both causes relate to the cultural selection role of politicians: politicians themselves are at the centre of the crisis of the political system. The ability of the political system to evolve and adapt to the new social environment, attracting potential new members, will determine its potential to survive in the future.

\section{References}

Abbott, A. (1988). The System of Professions: An Essay on the Division of Expert Labor. Chicago, IL: University of Chicago Press.

Barnes, S. H., Kaase, M. (Eds.). (1979). Political Action: Mass Participation in Five Western Democracies. Beverly Hills: Sage.

Blais, A., Gidengil, E., Nevitte, N., Nadeau, R. (2004). Where Does Turnout Decline Come from? European Journal of Political Research 43, 221-236.

Bourgeault, I. L., Benoit, C., Hirschkorn, K. (2009). Introduction: Comparative Perspectives on Professional Groups: Current Issues and Critical Debates. Current Sociology 57, 475-485.

Buzzi, C., Cavalli, A., de Lillo, A. (2007). Rapporto giovani. Sesta indagine dell'Istituto IARD sulla condizione giovanile in Italia. Bologna: il Mulino.

Calegari, P., Massimini, F. (1978). Psicologia dell'artefatto normativo sociale. Milano: Franco Angeli.

Cavalli-Sforza, L. L., Feldman, M. W. (1981). Cultural Transmission and Evolution: A Quantitative Approach. Princeton: Princeton University Press.

Crainz, G. (2009). Autobiografia di una Repubblica. Le radici dell'Italia attuale. Roma: Donzelli editore.

Craveri, P. (1996). La Repubblica dal 1958 al 1992. Milano: TEA.

Dalton, R. J. (1988). Citizen Politics in Western Democracies. Chatham, NJ: Chatham House.

Dalton, R. J. (2007). The Good Citizen: How a Younger Generation is Reshaping American Politics. Washington: Congressional Quarterly Press.

Dawkins, R. (1976/2006). The Selfish Gene. New York: Oxford University Press.

Evetts, J. (1999). Professional Identities; State and International Dynamics in Engineering. In I. Hellberg, M. Saks, C. Benoit (A cura di). Professional Identities in Transition, pp.13-25. Landskrona: Parajett.

Evetts, J. (2003). The Sociological Analysis of Professionalism: Occupational Change in the Modern World. International Sociology 18 (2), 395-415.

Evetts, J. (2006). Short Note: The Sociology of Professional Groups: New Directions. Current Sociology 54, 133-143.

Galli della Loggia, E. (1980). La crisi del "politico". In E. Galli della Loggia, M. Bianchi, N. Aspesi, U. Volli, A. M. di Nola, R. Simone, N. Ajello. Il trionfo del privato. Roma-Bari: Laterza.

Gardner, H. (2005). Compromised Work. Daedalus 134 (3), 42-51.

Gardner, H. (2006). Five Minds for the Future. Boston: Harvard Business School Press.

Gardner, H. (2007). Irresponsible Work. In H. Gardner (Ed.). Responsibility at Work: How Leading Professionals Act (Or Don't Act) Responsibly. San Francisco, CA: Jossey-Bass. 
Gardner, H. (2010). What it Means to be a Good Person, a Good Worker, and a Good Citizen. 5th European Conference on Positive Psychology, pp. 130-131. www.ecpp2010.dk.

Gardner, H., Csikszentmihalyi, M., Damon, W. (2001). Good Work: When Excellence and Ethics Meet. New York: Basic Books.

Gardner, H., Gregory, A., Csikszentmihalyi, M., Damon, W., Michaelson, M. (2001). The Empirical Basis of Good Work: Methodological Considerations. Taken in October 2008 from www. goodworkproject.org.

GoodWork Project Team. (2008, May). The GoodWork Project: An Overview. Taken in January 2009 from www.goodworkproject.org.

Horn, L., Gardner, H. (2007). Constraining Responsibility. In H. Gardner (A cura di). Responsibility at Work: How Leading Professionals Act (Or Don't Act) Responsibly. San Francisco, CA: JosseyBass.

Inghilleri, P. (1999). From Subjective Experience to Cultural Change. New York: Cambridge University Press.

Jablonka, E., Lamb, M. J. (2005). Evolution in Four Dimensions: Genetic, Epigenetic, Behavioural And Symbolic Variations in The History of Life. Cambridge, MA: MIT Press.

Lyons, W., Alexander, R. (2000). A Tale of Two Electorates: Generational Replacement and the Decline of Voting in Presidential Elections. Journal of Politics 62 (4), 1014-1034.

Massimini, F., Calegari, P. (1979). Il contesto normativo sociale. Teoria e metodo di analisi. Milano: Franco Angeli.

Milbrath, L. W. (1965). Political Participation: How and Why Do People Get Involved in Politics? Chicago, IL: Rand McNally.

Miller, W. E., Shanks, J. M. (1996). The New American Voter. Cambridge, MA: Harvard University Press.

Orzack, L. H. (1998). Professions and World Trade Diplomacy: National Systems and International Authority. In V. Oligati, L. H. Orzack, M. Saks (Eds.). Professions, Identity and Order in Comparative Perspective, pp. 13-37. Onati: International Institute for the Sociology of Law.

Petracca, M. (1991). The Poison of Professional Politics. Policy Analysis, Cato Institute 151, 10 May.

Shennan, S. (2008). Canoes and Cultural Evolution. Proceedings of the National Academy of Sciences of the United States of America 105 (9), 3175-3176.

Vergani, M. (2011). Are Party Activists Potential Opinion Leaders? Javnost - The Public 18, 71-82.

Weber, M. (1919). Politics as a Vocation. In H. H. Gerth and C. Wright Mills (Eds.). From Max Weber: Essays in Sociology, pp. 77-128. New York: Oxford University Press.

Geography and Environmental Human Sciences,

University of Milan,

via Festa del Perdono 7,

Milano, 20133

Italy

E-mail: marcoboffipsy@gmail.com 